\title{
Two Unnoticed Poems Probably Written by Pierre Corneille
}

Author(s): H. Carrington Lancaster

Source: The Modern Language Review, Vol. 10, No. 2 (Apr., 1915), pp. 226-227

Published by: Modern Humanities Research Association

Stable URL: http://www.jstor.org/stable/3713562

Accessed: 06-03-2016 13:14 UTC

Your use of the JSTOR archive indicates your acceptance of the Terms \& Conditions of Use, available at http://www.jstor.org/page/ info/about/policies/terms.jsp

JSTOR is a not-for-profit service that helps scholars, researchers, and students discover, use, and build upon a wide range of content in a trusted digital archive. We use information technology and tools to increase productivity and facilitate new forms of scholarship. For more information about JSTOR, please contact support@jstor.org. 


\title{
Two Unnoticed Poems probably written by Pierre Corneille.
}

The two following poems, signed 'P.C.,' are found in the introductory pages to La Melize pastorale comique par le Sieur du Rocher, Paris, $1634^{1}$ :

\author{
Au Sieur du Rocher.
}

$\mathrm{Au}$ point ou l'on vois [sic] tes escrits

Ie croy que tous les beaux esprits,

Seront charmez de tes merueilles,

Et l'on peut iuger aysement,

Qu'il n'est point de contentement,

Apres le doux fruict de tes veilles.

$$
\text { P.C. }
$$

Les Poetes a Monsieur du Rocher, sur ces Princes recognus.

De quelle assez digne louange,

Peut on honorer tes escris

Puisqu'on les reconnoist sans pris,

Et digne mil[le] fois de l'estime d'un Ange:

$\mathrm{Au}$ dessein de loüer un esprit si parfaict

Tous nos desirs n'ont point d'effect,

Icy nostre puissance à [sic] trouué des limites,

Mais quoy tes soings seront mieux recongus [sic],

Puisque ces Princes Inconus [sic],

Vont publier pour nous ta gloire et tes merites.

$$
\text { P.C. }
$$

Corneille is more likely to have been the author of these lines than any of his contemporaries with the same initials. Between 1631 and 1635 he wrote four similar poems to Scudéry, Mareschal, and La Pinelière ${ }^{2}$, authors who, at the time they received his praises, were scarcely better known than this obscure Du Rocher. Although he ordinarily signed himself 'Corneille,' he has left an example of the 'P.C.' signature at the end of a poem published in the Mercure galant for March 7, 16803. His praise of Du Rocher is no more absurd than that which he gave to Mareschal and La Pinelière, or than that which he lavished upon Boisrobert, whose mention of him in an Epistle will, he assures the grotesque abbé, bring him greater fame than Cinna, Rodogune, the Cid, and Horace 4 . Finally, the device, found in the second poem, of referring to characters in the play praised recurs in Corneille's complimentary verses to other dramatists.

1 Privilege, February 3.

2 Cf. Marty-Laveaux, Euvres de P. Corneille, x, pp. 57, 61, 62, 73.

3 Op. cit., $\mathrm{x}, \mathrm{p}$. 334. The editor of the journal states that the poem was written by Pierre Corneille.

Op. cit., x, p. 103. 
None of these facts, of course, proves that Corneille wrote the verses, but they do show that there is nothing improbable in assigning to him their authorship. On the other hand, I can find no name that fits the initials so well as his. It is true that a score of men of this period can be mentioned who had similar initials, but they were, for the most part, theologians, like Pierre Champeil or Philippe Codurc, jurists, like Pierre Canon or Philippe Cothereau, an artist, Philippe de Champagne, a diplomat, Pierre Chanut, a physician, Philippe Colot. The only men of letters I find are Jean-Pierre Camus, Prudent Constant, Pierre Costar, Pierre de Caseneuve, none of whom was a dramatist, only one a poet, and Pierre de Cotignon Sieur de La Charnaye, who was, indeed, both poet and dramatist, but whose name seems hard to reduce to a simple 'P.C.'

Moreover, Corneille was already a well-known dramatist, the author by the year 1634 of six plays recognized by his contemporaries as among the most important of the period. Introductory poems in praise of plays were usually written by dramatists. Hence the initials in question, attached to poems addressed to a playwright, would so readily be attributed to Corneille that their use by another would seem almost a forgery. It is therefore highly probable that the poems were written by Corneille.

Is it to be argued from this conclusion and from the fact that $\mathrm{Du}$ Rocher ${ }^{1}$, like Mareschal and Scudéry, devoted his plays largely to setting forth impossible romantic adventures, that Corneille had at this time a special admiration for that kind of drama? I think not, for by 1634 he had himself written five comedies of manners and only one tragi-comedy, and, since his contemporaries published only plays of the latter type or equally romantic pastorals and comedies, he was obliged, in order to praise any other plays than his own, to turn to the work of such men as Scudéry and Du Rocher. Later, the popularity of introductory verses waned, so that it is not surprising to find that these romantic plays are almost the only ones favoured by Corneille with praise. It is probable that in such verses he is not stating a genuine opinion, but is merely using a conventional means of expressing his friendship for certain of his contemporary dramatists.

Amherst, Mass., U.S.A.

\section{H. Carrington Lancaster.}

1 The only thing known about this author, besides his writing Melize, is the fact that he composed a tragi-comedy called l'Indienne amoureuse ou l'heureux naufrage (privilege, June 14, 1631), in which he adorns a subject taken from Ariosto with all the conceits and extravagances familiar to this variety of drama. 